\title{
PENYEMBUHAN BABY BLUES SYNDROME DAN POST-PARTUM DEPRESSION MELALUI CHANDRA NAMASKARA DAN BRAHMARI PRANAYAMA
}

\author{
Oleh: \\ Ni Wayan Sri Prabawati Kusuma Dewi \\ Dosen pada Fak. Dharma Acarya IHDN Denpasar \\ Email : sriprabawati89@gmail.com
}

\begin{abstract}
:
Babies born through both normal and caesarean (sc) procedures, 50-80\% make the mother face the risk of baby blues syndrome and post-partum depression. Baby blues syndrome, occurs in the first 2 weeks after giving birth, triggered by physical changes such as swelling of the breast, pain in the area around the birth canal and uterus, changes in muscle tone, physical and mental fatigue that the mother feels. While post-partum depression lasts several months to many years later, this syndrome begins with a psychiatric disorder suffered by the mother before pregnancy, psychosocial stress, inadequate social support, and premenstrual dysphoric disorder. For that, this condition needs to be addressed immediately, through the healing techniques of Chandra namaskara and Brahmari Pranayama. Chandra namaskara arouses the feminine energy, the lunar energy in the mother's body, keeping the cerebral circulation fresh so that the sympathetic nerve activity diminishes. The effect of massage on the organs in the abdomen, increase peristaltic activity in the intestine, the lateral wall of the heart stretched perfectly so that no ischaemia occurs. Alteration of arthritis of the spinal joint can be removed by stretching the spinal muscles and ligaments between the vertebral bones through this series of asanas. While brahmari pranayama stimulates the brain part of the hypothalamus to activate the adrenal cortex system by sending signals to the pituitary gland so as not to secrete adrenocorticotropin (ACTH), so that ACTH, which had previously stimulated the outer layer of the adrenal glands (the adrenal cortex) to release a group of hormones (cortisol) did not secrete cortisol, but instead produced by the brain is actually the endhorpine that works for the body's immune, regulate emotions, relax of the body and be able to eliminate depression.
\end{abstract}

Keywords: Baby blues syndrome, Post-partum depression, Chandra namaskara, Brahmari Pranayama.

\section{ABSTRAK}

Bayi yang lahir baik melalui prosedur normal maupun caesar (sc), 50-80\% membuat ibunya menghadapi resiko baby blues sindrom dan post-partum depression. Baby blues sindrom, terjadi pada 2 minggu pertama setelah melahirkan, dipicu oleh perubahan fisik seperti payudara yang membengkak, rasa sakit di daerah sekitar jalan lahir dan rahim, perubahan tonus otot serta kelelahan fisik maupun mental yang dirasakan ibu. Sedangkan post-partum depression berlangsung dalam beberapa bulan hingga bertahun-tahun setelahnya, sindrom ini diawali dengan adanya bakat gangguan kejiwaan yang diderita oleh si ibu sebelum mengalami kehamilan, stress psikososial, dukungan sosial yang tidak memadai, dan gangguan dysphoric premenstrual. Untuk itu, kondisi ini perlu segera diatasi, melalui teknik penyembuhan Chandra namaskara dan brahmari pranayama. Chandra namaskara membangkitkan energi feminim, energi lunar dalam tubuh ibu, menjaga sirkulasi serebral tetap segar sehingga aktifitas saraf simpatik berkurang. Efek pijatan pada organ dalam perut, meningkatkan aktivitas peristaltik pada usus, dinding lateral pada jantung meregang dengan sempurna sehingga tidak terjadi ischaemia. Sirkulasi atau perubahan artritis pada sendi tulang belakang dapat dihilangkan dengan peregangan pada otot-otot para spinal dan ligament antar tulang vertebra melalui serangkaian asanas ini. Sedangkan brahmari pranayama, merangsang bagian otak yakni, hipotalamus untuk melakukan aktivasi sistem korteks adrenal dengan mengirim sinyal ke kelenjar hipofisis agar tidak mensekresikan adrenocorticotropin (ACTH), sehingga ACTH yang tadinya menstimulasi lapisan luar kelenjar adrenal (korteks adrenal) untuk melepaskan sekelompok hormon (kortisol) justru tidak mensekresikan kortisol, namun sebaliknya yang dihasilkan oleh otak justru endhorpine yang berfungsi untuk kekebalan tubuh, mengatur emosi, merilekskan tubuh serta mampu menghilangkan depresi.

Kata Kunci: Baby blues sindrom, Post-partum depression, Chandra namaskara, Brahmari Pranayama. 


\section{PENDAHULUAN}

Menilik perjalanan sejarah di Indonesia, Hari Ibu dirayakan secara nasional pada tanggal 22 desember, tanggal ini diresmikan oleh Presiden Soekarno di bawah Keputusan Presiden Republik Indonesia No.316 tahun 1959, pada ulang tahun ke-25 Kongres Perempuan Indonesia tahun 1928 (https://id.wikipedia.org/wiki/Hari_Ibu). Nampaknya organisasi wanita yang telah ada sejak tahun 1912, menginspirasi Presiden Soekarno untuk menetapkan tanggal 22 desember sebagai perayaan nasional untuk merayakan semangat wanita Indonesia atas jasa-jasanya yang turut berjuang waktu itu sebagai pejuang wanita merebut kemerdekaan dan meningkatkan hak-hak perempuan di bidang pendidikan dan pernikahan. Belakangan, hari Ibu dimaknai sebagai hari perayaan khusus mengenang jasa ibu di seluruh tanah air atas segala jasa dan perannya dalam keluarga, baik untuk suami, lingkungan sosial, terutama karena telah melahirkan dan mendidik anak-anaknya tanpa pamrih. Sementara di Amerika dan lebih dari 75 negara lain seperti Australia, Kanada, Jerman, Italia, Jepang, Belanda, Malaysia, Singapura, Taiwan dan Hongkong, Hari ibu atau Mother's Day dirayakan pada hari minggu di pekan kedua bulan Mei. Di beberapa Negara Eropa dan Timur Tengah, hari perempuan internasional atau international women's day diperingati setiap tanggal 8 maret.

Fenomena ini menunjukkan bahwa wanita, terutama perannya sebagai Ibu memiliki tempat khusus dihati setiap masyarakat dunia. "jika ibu wajahnya selalu memancarkan keceriaan, seluruh rumah tangga berbahagia, tetapi jika wajahnya cemberut, semuanya akan kelihatan suram"(Manavadharmasastra, III.62). Berbicara mengenai Ibu, perhatian kita tertuju pada sebuah keluarga (keluarga inti) yang terdiri atas ayah, ibu dan anak-anak. Berkeluarga (Grahastha asrama) merupakan tahapan hidup kedua pada ajaran agama Hindu, setelah melalui tahapan masa menuntut ilmu ( Brahmacari asrama), tahapan ini diawali dengan upacara vivaha samskara sebagai simbol penyatuan. Lebih lanjut di dalam kitab Manavadharmasastra disebutkan kewajiban sebagai suami-istri yakni, (1) Dharmasampati; suami-istri secara bersama-sama melaksanakan ajaran dharma yang meliputi semua aktivitas dan kewajiban hidup sesuai ajaran agama, (2) Praja; suami istri mampu melahirkan keturunan (putra-putri) yang suputra, berkualitas yang akan melanjutkan amanat dan kewajiban leluhur, (3) Rati; suami-istri dapat menikmati kepuasan seksual dan kepuasan lainnya, artha dan kama yang tidak bertentangan dengan dharma .

Kewajiban suami-istri untuk melahirkan putra-putri yang suputra (Praja), lebih dimaknai erat dengan kemampuan melahirkan secara fisik, yakni anak-anak lahir (biologis) dari ayah dan ibu-nya. Hal ini menuntut wanita terutama, untuk memenuhi kodratnya sebagai ibu yang mampu mengandung dan mendidik anak-anaknya agar menjadi anak yang suputra. Oleh sebab itu, kehamilan merupakan hal wajib yang mesti dialami oleh seorang wanita agar mampu menggandeng predikat sebagai ibu secara utuh dalam sebuah tatanan sosial masyarakat. Perlu disadari, bahwa walaupun sesuai kodratnya wanita terlahir untuk menjadi seorang ibu melalui rahimnya, namun kehamilan dan melahirkan bukanlah sebuah proses yang mudah. Data kementrian kesehatan menunjukkan, pada tahun 2011-2015 terdapat sekitar 130-200 kasus kematian ibu melahirkan dari 100.000 kasus yang selamat.

Mengapa hal ini bisa terjadi ? penyebabnya dapat dikarenakan berbagai faktor, baik dari sisi kesehatan ibu, janin, maupun fasilitas rumah sakit yang kurang memadai. Adapun penyebab ibu meninggal saat proses bersalin adalah sebagai berikut:(1) pendarahan, (2) hipertensi/ preeklampsia, (3) Rahim robek/repture uteri, (4) gangguan pernafasan akut, (5) proses bersalin yang berlangsung lama, (6) infeksi, (7) aborsi, (8) sepsis, (9) anemia, (10) malaria, (11) hepatitis, (12) penyakit jantung dan (13) HIV/Aids. Demikian kompleks resiko yang mesti dialami oleh seorang wanita ketika berjuang melahirkan bayinya ke dunia, ketika perjuangan bersalin berakhir dan akhirnya si buah hati yang ditunggu-tunggu lahir baik melalui proses normal maupun caesar (sc), si ibu mesti menghadapi resiko selanjutnya yang $50-80 \%$ dialami oleh ibu pasca melahirkan baik disadari ataupun tidak. Resiko itu kerap disebut 
dengan baby blues sindrom dan post-partum depression.

Memang terdengar aneh, perasaan senang menanti-nanti kehadiran sang buah hati ternyata pada sebagian ibu dapat berubah menjadi depresi. Baby blues sindrom adalah perasaan sedih dan gundah yang dialami ibu pasca melahirkan bayinya, sindrom ini masih tergolong ringan dan biasanya dialami setelah ibu pulang dari rumah sakit bersalin sampai 2 minggu setelah melahirkan. Jika sindrom ini berlanjut lebih dari 2 minggu, maka ibu akan mengalami kondisi mental yang lebih serius mengarah ke kejiwaan yang dikenal dengan istilah post-partum depression. Lantas apa perbedaan antara baby blues sindrom dengan post-partum depression ? perbedaannya terletak pada frekuensi, intensitas, durasi berlangsungnya. Kedua sindrom ini dapat dibedakan lebih lanjut dengan memperhatikan pola tidur si ibu. Jika ketika ada orang lain membantu menjaga bayinya, dan ibu bisa tertidur, maka besar kemungkinan si ibu hanya mengalami baby blues sindrom. Namun, jika si ibu sangat sulit tertidur walaupun ada orang lain yang turut membantu menjaga bayinya, maka tingkat depresinya sudah masuk ke dalam postpartum depression. Post partum depression dapat berlangsung hingga satu tahun bahkan bertahuntahun sejak kelahiran bayinya. Pada kasus postpartum depression akut si ibu bisa saja bunuh diri atau menyakiti bayinya sendiri pada tahun-tahun berikutnya.

Sepertikasusyang terjadidi Tangerang, Banten tahun 2008 seorang ibu tega membunuh bayinya yang baru berusia enam bulan, dan setelahnya si ibu berusaha bunuh diri. Begitupun kasus yang terjadi di Desa Jimbe, Jenangan, Ponorogo, Jawa timur tahun 2013, seorang ibu juga membunuh bayinya yang baru berusia empat minggu. Setelah dilakukan pemeriksaan, diduga si ibu mengalami post-partum depression akut. Baru-baru ini, bulan februari 2018, di Banjar Palak, Sukawati, Gianyar, seorang ibu yang berprofesi sebagai guru juga membunuh ketiga anaknya yang masing-masing berusia enam tahun, empat tahun, dan dua tahun. Setelah berhasil membunuh ketiga anaknya, si ibu kemudian berusaha bunuh diri dengan meminum racun serangga, diduga si ibu mengalami depresi akibat bermasalah dengan suami dan keluarga besarnya. Tidak hanya di Indonesia, rupanya di Ohio, Amerika serikat bulan oktober tahun 2016 silam, seorang ibu memutilasi anaknya yang baru berusia satu tahun, hasil pemeriksaan menunjukkan si ibu mengalami depresi berat. Organisasi Kesehatan Dunia (WHO) mendifinisikan depresi sebagai gangguan kesehatan mental yang umum dengan gejala kesedihan, hilang ketertarikan pada hal-hal yang menyenangkan. Merasa bersalah, lelah, dan tak berharga, sehingga sulit tidur maupun berkonsentrasi. Dalam publikasinya di Harvard Health Publication, pada bulan Juni tahun 2009, tim dari Harvard Medical School menyebutkan, kegagalan otak mengatur mood, kerentanan genetika, peristiwa-peristiwa yang menekan bhatin, hingga masalah kesehatan dan pengobatannya, bisa saling berinteraksi sehingga muncul depresi.

Seperti yang kita ketahui, depresi merupakan suatu sindrom yang terjadi akibat gangguan berbagai proses yang terjadi di dalam otak. Para peneliti menemukan bahwa dibandingkan dengan orang yang tidak menderita gangguan depresi, otak seorang penderita depresi seringkali menunjukkan peningkatan aktivitas di bagian otak yang memproses emosi, amigdala. Amigdala akan tampak sangat aktif pada seorang penderita depresi. Berbagai penelitian lainnya menduga bahwa peningkatan aktivitas amigdala ini terjadi akibat adanya perubahan emosi seperti rasa marah, sedih dan takut. Saat mengalami depresi, kemampuan untuk berfikir, belajar dan mengingat suatu informasi juga akan ikut terganggu, hal ini dikarenakan depresi dapat memicu peningkatan produksi hormone stress, kortisol yang dapat merusak atau membuat bagian otak tertentu menjadi lebih kecil dengan cara menghambat pembentukan sel saraf dan jaringan saraf baru. Suatu bagian otak yang disebut dengan hipokampus, mengalami pengecilan antara 9-13\% pada seorang wanita yang pernah menderita depresi.

Otak, pikiran, perasaan dan tubuh kita bervibrasi dengan frekuensi getaran tertentu. Ada yang mempunyai vibrasi dengan frekuensi yang rendah mulai dari $1 \mathrm{~Hz}, 1 / 2 \mathrm{~Hz}, 1 / 3 \mathrm{~Hz}, 1 / 4 \mathrm{~Hz}$, 
dan $1 / 5 \mathrm{~Hz}$. Sebaliknya ada juga yang bervibrasi dengan frekuensi yang tinggi mulai dari $2 \mathrm{~Hz}$, $3 \mathrm{~Hz}, 4 \mathrm{~Hz}, 5 \mathrm{~Hz}, 6 \mathrm{~Hz}$, bahkan sampai $19 \mathrm{~Hz}$. Saat ini vibrasi sudah dapat diukur oleh para ahli kesehatan dengan mengukur bentuk dan frekuensi gelombang otak. Dari hasil penelitian para ahli, ternyata otak manusia memancarkan gelombang tertentu dengan kecepatan cahaya sebesar 299.792,46 kilometer per detik. Saat ini telah diperoleh beberapa pola gelombang otak dengan frekuensi yang berbeda-beda yaitu, gelombang Alpha, Beta, Gamma, Delta, dan Theta. Hasil penelitian terakhir adalah gelombang Epsilon, yang ditemukan oleh Dr. Jeffrey D. Thompson, D.C,B.F.A dari Neuroacoustic Research dengan menggunakan alat EEG (Electroencephalograph) yang ditempelkan pada kepala manusia. Gelombang Epsilon muncul saat orang sedang dalam kondisi bermeditasi dengan pola dan frekuensi otak manusia di bawah $0.5 \mathrm{~Hz}$ atau di bawah $1 / 2 \mathrm{~Hz}$. Gelombang otak yang masih dalam kondisi normal adalah gelombang Delta, sedangkan yang paling sehat adalah gelombang Epsilon, ketika seseorang berada dalam kondisi gelombang Epsilon, ia akan berada dalam : (1) kondisi keseimbangan antara otak kiri dan otak kanan, (2) kondisi meditasi sangat hening, (3) kondisi untuk mendapat inspirasi dan intuisi yang berkualitas, dan (4) kondisi spiritual yang lebih tinggi (Gondosari, Aleysius H, 2010: 58-61)

Gelombang Epsilon dapat dicapai melalui meditasi yang hening, dan hal ini bukanlah perkara yang mudah terutamanya untuk ibu pasca melahirkan yang rentan terjangkit baby blues sindrom dan post-partum depression. Oleh sebab itu, sangatlah mendesak sifatnya untuk ibu menjalani sebuah teknik penyembuhan khusus yang bertujuan meredakan dan menghilangkan depresi yang dialami, yakni melalui Chandra namaskara, dan brahmari pranayama. Mengapa teknik ini disarankan? sebab mempertimbangkan kondisi fisik dan rahim ibu baru akan berangsur pulih setelah tiga bulan pasca melahirkan baik melalui proses normal maupun caesar (sc).

\section{PEMBAHASAN}

2.1 Pengertian, gejala dan penyebab baby blues sindrom dan post-partum depression.

Kebahagiaan terbesar seorang wanita adalah ketika dirinya telah melahirkan seorang bayi. Apa yang dapat membuat wanita lebih bahagia daripada peristiwa penting ini ? rasanya tidak ada, namun tak berapa lama setelah munculnya rasa haru dan bahagia itu, juga muncul perasaan sedih dan emosi. Gangguan kejiwaan ringan pasca melahirkan dapat timbul seperti baby blues sindrom atau yang tidak ringan seperti postpartum depression. Gangguan ini sering tidak diketahui secara pasti, tapi ibu tidak sendirian. Faktanya adalah bahwa sebanyak $80 \%$ wanita mengalami beberapa gangguan suasana hati dalam waktu setelah melahirkan (dikenal sebagai periode postpartum). Ibu merasa cemas, marah, sendirian, takut, atau tidak mengasihi bayinya, dan diperparah dengan munculnya rasa bersalah karena memiliki perasaan ini. Data statistik menunjukkan, untuk gejala gangguan seperti baby blues sindrom, dapat berangsur-angsur menghilang dengan semakin lekatnya bonding antara ibu dan bayi yang dimungkinkan dengan menurunnya tingkat kecemasan, ketakutan, rasa nyeri dan kelelahan ibu dengan dukungan suami dan keluarga melalui teknik penyembuhan khusus, namun $10-20 \%$ ibu pasca melahirkan justru tanpa disadari mengalami gangguan tingkat lanjut yang disebut dengan post-partum depression, dimana kondisi ini sangat perlu dikhawatirkan.

\section{Baby Blues sindrom}

Baby Blues sindrom atau sering disebut Postpartum Distress Syndrome adalah gangguan psikologis berupa sedih, cemas dan emosi meningkat yang dialami sekitar 50- 80\% wanita setelah melahirkan khususnya bayi pertama. Biasanya terjadi pada 2 minggu pertama setelah melahirkan, namun terlihat lebih berat pada hari ke-3 dan hari ke-4, apalagi si ibu dan bayi kembali ke rumah dan ibu mulai merawat bayinya sendiri. Beberapa ahli menduga baby blues sindrom terjadi karena tubuh ibu sedang mengalami perubahan secara fisik dan hormonhormon dalam tubuh juga mengalami perubahan yang besar ditambah kelelahan yang baru dialami saat melahirkan sehingga membuat ibu stress dan tidak tenang. Perubahan fisik seperti payudara 
yang membengkak, rasa sakit di daerah jalan lahir dan rahim, perubahan tonus otot, ikut memicu terjadinya baby blues sindrom. Tetapi penyebab utamanya adalah rasa teramat lelah yang dirasakan. Jika baby blues sindrom dialami lebih dari 2 minggu, hal ini mengindikasikan ibu sangat memerlukan perhatian suami, dukungan keluarga dan gejala ini sudah perlu dikhawatirkan.

Tanda dan gejala baby blues sindrom : (1) Adalah sebuah gangguan psikologis berupa emosi tinggi yang terjadi pada sekitar $50-80 \%$ wanita setelah melahirkan, (2) Gangguan ini mencapai puncak saat 3-5 hari setelah melahirkan dan berlangsung dari beberapa hari sampai beberapa minggu pasca melahirkan, (3) Ibu depresi dan lebih mudah menangis dari biasanya, merasa marah, sedih, gelisah dan emosional sehingga ibu mengalami gangguan tidur, (4) Ibu kurang perduli dengan bayinya, namun gejala ini tidak mengganggu kemampuan seorang ibu untuk merawat bayinya sendiri di saat-saat tertentu, (5) Emosi tak menentu, kerap tersinggung, kerap kehilangan kesabaran, (6) Ibu tidak percaya diri, cemas berlebihan, merasa bersalah dan tidak berharga, (7) cepat lelah dan mengalami pusing kepala.

\section{Post-partum depression}

Post-partum depression sering disebut depresi klinis yang terjadi segera setelah melahirkan. Beberapa profesional kesehatan menyebutnya depresi postpartum nonpsychotic.

Kondisi ini terjadi pada sekitar 10\% -20\% ibu pasca melahirkan, dan biasanya berlangsung dalam beberapa bulan hingga bertahun-tahun setelahnya. Sindrom ini diawali dengan adanya bakat gangguan kejiwaan yang diderita oleh si ibu sebelum mengalami kehamilan, stress psikososial, dukungan sosial yang tidak memadai, dan gangguan dysphoric premenstrual. Tanda dan gejala post-partum depression : (1) suasana hati tertekan, ketidakmampuan untuk menikmati kegiatan yang menyenangkan, kesulitan tidur, kelelahan dan berkurangnya nafsu makan, (2) pikiran tentang kematian, ingin bunuh diri dan membunuh bayinya, akibat perasaan tidak mampu sebagai orangtua, (3) Suasana sedih, sering menangis, perasaan penolakan, penurunan minat pada seks dan mengalami gangguan berat badan, (4) Kehilangan energi, agitasi atau kecemasan, perasaan tidak berharga atau bersalah, (5) Sulit berkonsentrasi atau membuat keputusan, (6) gejala fisik seperti sering sakit kepala, nyeri dada, denyut jantung cepat, mati rasa, kegoyahan atau pusing, dan sesak napas ringan yang menandakan kecemasan,(7) gejala ini mengganggu kemampuan seorang wanita untuk merawat bayinya.

\section{Penyebab dan Faktor Risiko :}

Sampai saat ini masih belum diketahui pasti penyebab gangguan tersebut. Tidak ada penyebab spesifik dari baby blues sindrom dan postpartum depression. Tetapi beberapa faktor diduga sebagai penyebab dan faktor resikonya, yaitu : (1) Perubahan hormonal, (2) Tingkat hormon estrogen, progesteron, dan kortisol turun drastis dalam waktu 48 jam setelah melahirkan, (3) Penyakit mental sebelum kehamilan, (4) Gangguan mental postpartum setelah kehamilan sebelumnya, (5) Konflik dalam pernikahan, kehilangan pekerjaan, atau dukungan sosial yang buruk dari teman dan keluarga, (6) Keguguran seperti keguguran atau lahir mati. Risiko depresi berat setelah keguguran tinggi untuk wanita yang memiliki anak, (7) Perubahan fisik setelah melahirkan, termasuk perubahan tonus otot dan kesulitan menurunkan berat badan, (8) Kelelahan fisik setelah melahirkan dan dalam minggu-minggu sesudahnya, (9) Nyeri dan rasa sakit di daerah perineum (daerah sekitar jalan lahir) membuat banyak wanita tidak nyaman. Pada kasus melahirkan secara caesar (sc) pemulihan fisik dapat berlangsung lebih lama dari proses melahirkan secara normal, (10) Perubahan emosi yang terjadi setelah melahirkan, yakni berupa perasaan kehilangan identitas lama, merasa terjebak di rumah, merasa kewalahan dengan tanggung jawab sebagai ibu, merasa kelelahan karena pola tidur yang tidak teratur, merasa stress dari perubahan dalam rutinitas serta merasa kurang menarik secara fisik dan seksual. (https://dokterindonesiaonline.com/2014/08/21/ kenali-baby-blues-syndrome-dan-gangguan-jiwapaska-melahirkan-lainnya/) 


\subsection{Respon Hormonal Pada Ibu Yang Mengalami Baby Blues Sindrom Dan Post- Partum Depression}

Hormon adalah zat kimia yang disekresikan dalam cairan tubuh oleh suatu sel atau kelompok sel dan menimbulkan efek pengaturan fisiologis pada sel-sel lain tubuh. Hormon dihasilkan oleh kelenjar endokrin atau kelenjar buntu. Kelenjar ini merupakan kelenjar yang tidak mempunyai saluran sehingga sekresinya akan masuk aliran darah dan mengikuti peredaran darah ke seluruh tubuh. Apabila sampai pada suatu organ target, maka hormon akan merangsang terjadinya perubahan. Sistem hormonal terkait dengan sistem saraf yang berarti sistem hormonal tidak lepas dari adanya kerja sistem saraf. Misalnya kelenjar adrenal dan kelenjar hiposfisis akan mensekresi hormonnya hanya bila terdapat rangsangan dari sistem saraf yang sesuai. Fungsi berbagai hormon adalah mengatur tingkat aktivitas jaringan sasaran, mengubah reaksi kimia dalam sel, mengatur permeabilitas membran sel terhadap zat-zat khusus dan mengaktifkan mekanisme seluler spesifik. Faktor hormonal berupa perubahan kadar estrogen, progesterone, prolaktin, dan estriol yang terlalu rendah, menurunnya kadar estrogen secara drastis seketika setelah melahirkan juga memicu munculnya baby blues sindrom dan post-partum depression sebab estrogen memiliki efek serupsi aktivitas enzim non adrenalin maupun serotin yang berperan dalam suasana hati, dan depresi.

Menurut Seyle dalam (Asiyah, 2010:107), stress adalah respon non spesifik dari badan terhadap setiap tuntutan yang dibuat atasnya. Reaksi pertama terhadap setiap jenis stress adalah kecemasan. Selanjutnya, kecemasanituakan diikuti oleh tahap perlawanan dan pengerahan kimiawi dari sistem pertahanan tubuh. Bila ancaman terjadi secara berkepanjangan, maka tubuh akan kehabisan energi untuk melawan ancaman itu dan sistem pertahanan tubuh akan berkurang. Stress tidak hanya merupakan pembunuh, tetapi juga merupakan kekuatan merusak yang drastik. Tiap orang memiliki perlawanan herediter yang berbeda-beda untuk melawan stress, tetapi sekali adaptasi energi seorang habis terkuras, maka tidak ada jalan untuk mengembalikan lagi. Sumber stress atau penyebab stress dikenal sebagai stressor. Stressor dapat dibagi menjadi tiga golongan yakni; (1) stressor fisik biologis: adalah stressor yang berasal dari kondisi fisik seseorang misalnya dingin, panas, infeksi, nyeri dan lain-lain, (2) stressor psikologis : stressor yang bersumber dari psikis, misalnya takut, cemas, marah, khawatir dan lain-lain. (3) stressor sosial budaya : stressor yang berasal dari kultur yang melatarbelakangi kehidupan seseorang, misalnya perceraian, perselisihan, pengangguran dan lain-lain. Melihat ketiga golongan penyebab stress di atas, dapat disimpulkan bahwa dalam kasus baby blues sindom dan post-partum depression; (1) stressor fisik biologis : muncul dari perubahan hormon secara drastis, rasa nyeri pada payudara yang membengkak, nyeri pada daerah sekitar jalan lahir dan rahim, perubahan tonus otot dan kesulitan menurunkan berat badan, serta kelelahan yang memuncak pasca persalinan, (2) stressor psikologis: muncul dari rasa takut, cemas dan khawatir berlebihan dalam menggeluti perannya sebagai ibu, merasa kehilangan identitas lama, hilangnya rasa percaya diri, merasa kurang menarik secara fisik dan seksual, (3) stressor sosial budaya: ketidaksepahaman dengan suami dan keluarga, kurangnya perhatian dari suami dan orang terdekat dalam membantu merawat diri dan bayinya, juga dapat muncul akibat tuntutan adat terkait serangkaian pelaksanaan kegiatan adat setempat yang ditujukan untuk menyambut kelahiran bayinya.

Akibatnya tubuh bereaksi terhadap stressor tersebut dan dimulainya seurutan kompleks respons bawaan terhadap ancaman yang dihadapi. Jika ancaman dapat dihentikan dengan segera, maka respons darurat tersebut akan seketika menghilang dan kondisi fisiologis kembali normal, namun apabila depresi ini tidak segera ditangani, maka akan menyebabkan kerugian pada beberapa aspek, yakni: (1) akibat fisik: munculnya penyakit jantung dan pembuluh darah (kardiovaskuler), gangguan pada saluran pernafasan dan pencernaan, pertumbuhan jaringan dan tulang, nyeri kepala, ketegangan otot, dan penurunan sistem kekebalan tubuh yang mengakibatkan ibu rentan terserang infeksi. (2) akibat emosional : ibu cenderung mengisolasi diri dan menarik diri dari lingkungan 
sosialnya, juga besar kemungkinan memiliki niat bunuh diri dan membunuh anaknya sendiri. (3) akibat perilaku: mengakibatkan ibu mengalihkan perhatian pada hal-hal yang merugikan misalnya merokok, minum-minuman keras, menggunakan obat-obatan terlarang dan makan dalam jumlah berlebihan yang berakibat buruk bagi kesehatan ibu.

Golongan stressor apapun, secara otomatis mengakibatkan tubuh mempersiapkan diri untuk menangani keadaan darurat tersebut. Pada saat ini dibutuhkan energi yang cepat sehingga hati melepaskan lebih banyak glukosa untuk dijadikan sebagai sumber energi. Metabolisme meningkat sebagai persiapan untuk pemakaian energi, terjadi peningkatan kecepatan denyut jatung, peningkatan tekanan darah dan peningkatan pernafasan. Demikian pula endhorphin disekresikan, sel darah merah lebih banyak dilepaskan untuk membantu membawa oksigen, dan sel darah putih dihasilkan lebih banyak untuk melawan infeksi. Sebagian besar perubahan psikologis tersbut terjadi akibat aktivitas dari dua sistem neuro endokrin yang dikendalikan oleh hipotalamus, yaitu sistem simpatetik dan sistem korteks adrenal. hipotalamus merupakan bagian dari otak yang menjadi pusat stress karena fungsi gandanya dalam keadaan darurat, yaitu: (1) mengaktivasi cabang simpatis dari sistem saraf otonom, (2) Kedua, hipotalamus melakukan aktivasi sistem korteks adrenal dengan mengirim sinyal ke kelenjar hipofisis agar mensekresikan adrenocorticotropin (ACTH). ACTH menstimulasi lapisan luar kelenjar adrenal (korteks adrenal) yang menyebabkan pelepasan sekelompok hormon (kortisol) yang meregulasi kadar glukosa dan mineral tertentu di dalam darah.

Efek dari kortisol adalah sebagai berikut: (1) Kalorigenik, kortisol meningkatkan pembentukan energi dari pemecahan cadangan karbohidrat, lemak dan protein, ini akan menyebabkan penurunan berat badan yang cukup bermakna, (2) Meningkatkan respon simpatis, respon ini akan meningkatkan curah jantung yang akan memberikan keluhan berupa dada berdebardebar, (3) Menurunkan akumulasi sel darah putih dan reaksi peradangan pada tempat cedera. Hal ini akan menyebabkan kerentanan terjadinya infeksi dan memperlama penyembuhan luka, (4) Merangsang sekresi lambung, hal ini menyebabkan rusaknya mukosa lambung, biasanya terbentuk ulkus peptikum, (5) Menurunkan hormone gonadotropin releasing factor, pada wanita akan menghambat ovulasi, libido sedangkan pada lakilaki menghambat spermatogenesis dan libido, (6) Merangsang somatostatin, hal ini menyebabkan gangguan pertumbuhan. Stress meningkatkan pembentukan katekolamin di medulla adrenal. Pelepasankatekolamin(epinefrin dan norepinefrin) menyebabkan: (1) Peningkatan aliran darah ke otak, jantung dan otot rangka yang meningkatkan resiko stroke dan gangguan jantung, (2) Relaksasi otot polos usus yang menyebabkan konstipasi, (3) Glukoneogenesis yang meningkatkan pemecahan cadangan energi sehingga membuat lebih kurus, (4) Peningkatan denyut dan kontraktilitas jantung yang memberikan keluhan dada berdebar-debar.

\subsection{Chandra Namaskara, dan Brahmari Pranayama Sebagai Metode Penyembuhan}

\section{Chandra namaskara}

Chandra namaskara adalah refleksi dari surya namaskara, sama seperti bulan yang tidak memancarkan cahaya sendiri, tetapi memantulkan cahaya matahari. Untuk urutan asana, tidak berbeda dengan surya namaskara, kecuali ardha chandrasana dilakukan setelah ashwa sanchalanasana. Pada separuh putaran pertama ashwa sanchalanasana, kaki kiri dilempar ke belakang untuk mengaktifkan ida nadi, kekuatan bulan. Pada separuh putaran kedua, giliran kaki kanan yang dilempar ke belakang. Postur ini berfungsi untuk memperoleh keseimbangan dan konsentrasi, untuk jangka panjang efek yang ditimbulkan adalah menselaraskan antara nafas masuk, nafas keluar dan pengaturan nafas menjadi lebih panjang. Energi bulan mengalir di dalam ida nadi, bersifat sejuk, menenangkan dan kreatif, untuk membangun energi feminim dalam tubuh sehingga tercapai kekuatan mental mencapai kesadaran. Chandra namaskara paling baik dilakukan pada sore atau malam hari, saat bulan mulai terlihat atau saat fajar pada bulan purnama, sebab ke empat belas asanas Chandra namaskara berhubungan dengan fase bulan yaitu Shukla paksha dan Krishna paksha. Saat berlatih di malam 
hari, pastikan perut dalam kondisi kosong.

"Where as the twelve positions of surya namaskara relate to the twelve zodiac or solar phases of the year, the fourteen positions of Chandra namaskara relate to the fourteen lunar phases. In the lunar calendar the fourteen days before the full moon are known as Shukla paksha, the bright fortnight, and the fourteen days after the full moon are known as Krishna paksha, the dark fortnight" ( Saraswati, Swami Satyananda, 2013:175).

Adapun tata cara melakukan ke empat belas asanas chandra namaskara beserta juga mantramnya masing-masing adalah sebagai berikut :

\section{Pranamasana}

\section{Mantram “ Om Kameshvaryai Namaha”}

Teknik : berdiri dengan tegak, tumit dan jempol kaki kiri dan kanan bersentuhan. Punggung tegak lurus, kedua bahu agak ditarik ke belakang, tegak. Satukan kedua telapak tangan di depan dada seperti posisi berdoa. Lepaskan ketegangan pada leher dan pundak dan tutup mata, Pernafasan normal

Chakra : Anahata chakra.

Manfaat khusus : Meredakan sakit kepala, insomnia, dan menstabilkan tekanan darah.

\section{Hasta Uttahanasana}

Mantram “ Om Bhagamalinyai Namaha “

Teknik:Tarik nafas, angkat kedua lengan ke atas melewati kepala, kedua telapak tangan disatukan, bahu lebar terpisah. Kepala menghadap ke atas, pinggang stabil, tubuh bagian atas melengkung ke belakang.

Chakra : Vishuddhi chakra.

Manfaat khusus : Meregangkan organ dalam perut, melepaskan ketegangan pada leher dan lengan. Meluaskan pernafasan di dada.

\section{Padahastasana}

\section{Mantram "Om Nityaklinnayai Namaha “}

Teknik : Hembuskan nafas, turunkan kedua lengan dan telapak tangan. Tekuk tubuh ke depan sampai kedua telapak tangan menyentuh lantai di sebelah kaki kiri dan kanan yang bersentuhan, cobalah untuk menyentuhkan hidung pada kedua lutut.

Chakra : Swadhistana chakra.

Manfaat khusus : Mengatasi masalah sakit punggung, linu panggul dan tekanan darah tinggi.

\section{Ashwa Sanchalanasana}

Mantram " Om Bherundayai Namaha "

Teknik : Tarik nafas, lemparkan kaki kiri ke belakang, buka dada, bahu ditarik membuka ke belakang. Kepala tegak menghadap ke depan, kedua telapak tangan berada di lantai, mengapit telapak kaki kanan.

\section{Chakra: Ajna chakra.}

Manfaat khusus : memperkuat pinggul, otot kaki, menginduksi keseimbangan sistem saraf.

\section{Ardha Chandrasana}

Mantram " Om Vahnivasinyai Namaha “

Teknik :Tarik nafas, posisi kaki masih seperti pose sebelumnya, angkat kedua lengan dan kedua telapak tangan ke atas, satukan dan posisikan di atas kepala. Lengkungkan punggung dan kepala menghadap ke atas.

\section{Chakra : Ajna Chakra.}

Manfaat khusus : Melenturkan organ-organ perut, peregangan leher, bahu, punggung dan dada. Menginduksi keseimbangan sistem saraf.

\section{Parvatasana}

Mantram "Om Vajreshvaryai Namaha "

Teknik : Hembuskan nafas, turunkan telapak tangan ke lantai, lempar kaki kanan ke belakang, sejajar dengan kaki kiri. Lengkungkan tubuh sehingga membentuk segitiga dengan posisi kepala berada di antara kedua lengan, menghadap ke bawah.

\section{Chakra : vishuddhi chakra}

Manfaat khusus : Meregangkan bahu, punggung, otot paha dan tendon. Memperlancar sirkulasi darah.

\section{Ashtanga namaskara}

Mantram : "Om Dutyai Namaha “ 
Teknik : Tarik nafas dan segera hembuskan nafas, tangan dan kaki masih dalam posisi sebelumnya, turunkan kedua lutut, dada dan dagu ke lantai. Jari kaki kiri dan kanan tetap menempel di lantai.

\section{Chakra : Manipura chakra.}

Manfaat khusus : Menyembuhkan tekanan darah tinggi, memperlancar aliran darah ke jantung, mengatasi nyeri punggung, meningkatkan daya tahan tubuh.

\section{Bhujangasana}

\section{Mantram "Om Tvaritayai Namaha”}

Teknik : Tarik nafas, tangan dan kaki masih dalam posisi yang sama, dorong punggung ke depan, sehingga punggung melengkung ke atas, kepala mendongak ke atas. Dada dibuka, tekuk kedua siku dan dekatkan pada sisi kiri dan kanan tubuh.

\section{Chakra : Swadhisthana Chakra}

Manfaat khusus : Meredakan sembelit, melancarkan sistem pencernaan, mengaktifkan sistem reproduksi.

\section{Parvatasana}

Mantram : " Om Kulasundaryai Namaha “

Teknik : Hembuskan nafas, luruskan siku, dorong tubuh dan seluruh punggung ke dalam dengan diikuti oleh kepala, sehingga membentuk posisi kembali seperti gunung.

\section{Chakra : Vishuddi chakra}

Manfaat khusus : Meregangkan punggung, otot paha dan tendon, memperkuat pinggul, melancarkan sirkulasi darah.

\section{Ashwa Sanchalanasana}

\section{Mantram " Om Nityayai Namaha "}

Teknik : Tarik nafas dan segera hembuskan, Lempar kaki kanan ke depan sehingga berada di antara kedua telapak tangan yang menyentuh lantai. Lutut kiri menyentuh lantai, kepala menghadap ke depan.

\section{Chakra : Ajna chakra}

Manfaat khusus : memperkuat pinggul dan kaki serta menyeimbangkan sistem saraf.

\section{Ardha chandrasana}

Mantram “ Om Nilapatakinyai Namaha “

Teknik : Tarik nafas, posisi kaki kanan dan kiri masih dalam posisi sebelumnya. Angkat kedua lengan dan telapak tangan ke atas, satukan di atas kepala. Kepala mendongak menghadap ke atas.

\section{Chakra: Ajna chakra}

Manfaat khusus : Melenturkan organ perut, meregangkan pundak, leher, bahu dan pundak. Memperkuat otot kaki dan menyeimbangkan sistem saraf.

\section{Padahastanasana}

\section{Mantram " Om Vijayayai Namaha "}

Teknik : Hembuskan nafas, lemparkan kaki kiri ke depan sampai bersentuhan dengan kaki kanan. Kedua telapak tangan berada disamping kaki kanan dan kiri. Kepala menghadap ke bawah, berusaha mencium lutut, leher dan pundak rileks.

Chakra : Swadhisthana chakra

Manfaat khusus : menyembuhkan hernia perut, linu panggul, masalah nyeri punggung dan menstabilkan tekanan darah.

\section{Hasta Utthanasana \\ Mantram “ Om Sarvamangalayai Namaha “}

Teknik : Tarik nafas, angkat kedua lengan ke atas, satukan kedua telapak tangan. Kepala berada diantara kedua lengan dan menghadap ke atas. Pinggul stabil, lengkungkan punggung bagian atas ke belakang.

\section{Chakra : Vishuddhi chakra}

Manfaat khusus : Memperkuat otot inti, peregangan organ perut dan panggul. Mengaktifkan tenggorokan dan timus.

\section{Pranamasana}

\section{Mantram : " Om Jvalamalinyai Namaha "}

Teknik : Hembuskan nafas, turunkan kedua lengan. Satukan kedua telapak tangan dan posisikan di depan dada dalam posisi berdoa.

\section{Chakra : Anahata Chakra}

Manfaat khusus : Meredakan sakit kepala, insomnia, dan mengatur tekanan darah. 


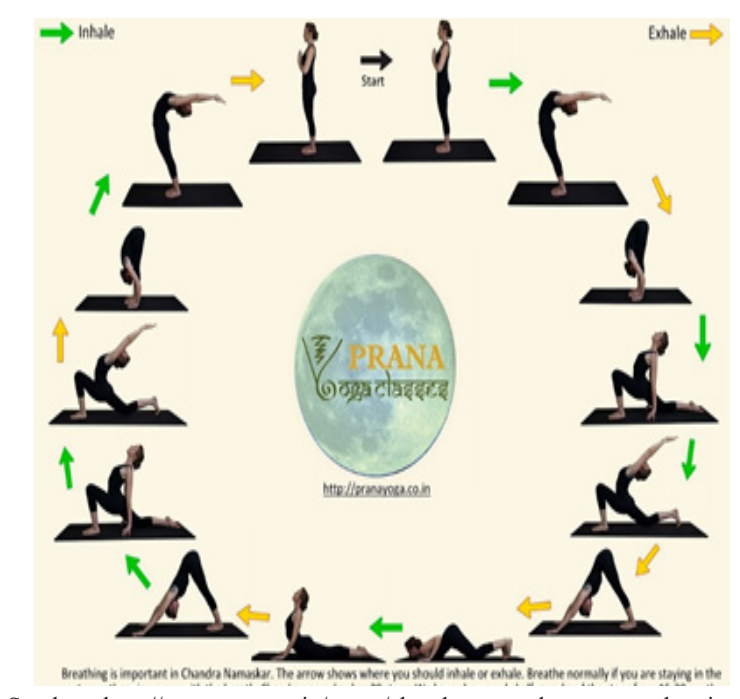

Sumber : http://pranayoga.co.in/asana/chandra-namaskar-moon-salutation/

Untuk ibu yang baru saja melahirkan dengan kondisi tubuh fisik yang masih merasakan nyeri hebat pada payudara dan daerah sekitar jalan lahir, baik pada ibu yang melahirkan dengan prosedur normal, dan mengalami beberapa jahitan di vagina maupun pada ibu yang melahirkan dengan prosedur caesar (sc) yang mengalami suntik epidural pada tulang belakang dan sayatan pada perut bagian bawah, chandra namaskara pada ibu dengan persalinan normal dapat dilakukan mulai hari ke-3 pasca melahirkan, dan mulai hari ke-7 untuk ibu dengan persalinan caesar (sc) sesuai kemampuan tubuh fisik ibu tersebut. Dapat diberlakukan kelas pemula pada ibu yang sebelumnya, tidak pernah sama sekali melakukan latihan yoga asanas, dan tahapan pemula-menengah pada ibu yang sebelumnya sudah pernah ikut latihan yoga asanas. Untuk bagaimana ibu menerapkan serangkaian tahapan chandra namaskara, tidak dipaksakan namun disesuaikan dengan kemampuan tubuh, lebih menekankan pada kenyamanan ibu itu sendiri. Chandra namaskara yang dilakukan oleh ibu, mampu membangkitkan energi feminim, energi lunar dalam tubuh, menstimulasi rasa tenang dan rileks. Chandra namaskara mampu merevitalisasi tubuh ibu dengan melonggarkan sendi-sendi yang kaku, membuka berbagai lobus paru-paru dan menjaga sirkulasi serebral tetap segar, sehingga aktifitas saraf simpatik berkurang, yang ditandai dengan berkurangnya tekanan darah dan denyut nadi hingga serendah 40-45. Asanas ini dapat membantu memulihkan kondisi ibu seperti setelah tidur lelap, hanya saja pemulihan berlangsung lebih cepat. Asanas secara konstan mampu melancarkan sistem sirkulasi darah sehingga tidak terbentuk penebalan pada dinding-dinding pembuluh darah, hal ini dapat dengan mudah diteliti tanpa perlu melakukan pembedahan.

Dengan rutin melakukan chandra namaskara, organ-organ dalam perut seperti hati dan limpa diregangkan, sel-selnya diaktifkan akibatnya metabolisme melambat yang ditandai dengan teraturnya denyut jantung pada ibu sehingga tekanan darah menjadi stabil. Semua organ-organ dalam perut terhindar dari pergeseran posisi, efek seperti pijatan yang diberikan pada organ dalam perut menghasilkan sirkulasi darah yang lebih baik dan meningkatkan aktivitas peristaltik pada usus. Dinding lateral pada jantung meregang dan kencang dengan sempurna sehingga tidak terjadi ischaemia (kekurangan suplai darah). Asam laktat tidak terbentuk dalam otot sebagaimana postur ini yang bersifat lembut, mengalir seperti air, sehingga sering juga disebut dengan jala asanas. Secara khusus, pranamasana, hasta uttahanasana, padahastasana, ashwa sanchalanasana, dan ardha chandrasana mampu mengurangi tekanan udara pada sendi antar tulang vertebra dan membantu mengurangi rasa sakit pada punggung dan pinggang ibu. Postur tersebut menghasilkan traksi alami pada kolom tulang belakang, mengembalikan kekuatan intrinsik pada otot yang dapat mencegah terjadinya prolapsed disc di kemudian hari. Semua masalah pada rangka dan otot merupakan masalah mekanis, sehingga harus ditangani secara mekanis juga. Penataan kembali otot-otot para-spinal dapat menghilangkan perubahan tekanan dan ketegangan pada syaraf tulang belakang dan menguatkan kembali hubungan anatominya. Sirkulasi atau perubahan artritis pada sendi tulang belakang dapat dihilangkan dengan peregangan pada otototot para-spinal dan ligamen antar tulang vertebra melalui serangkaian asanas Chandra namaskara ini.

\section{Brahmari Pranayama}

Kehidupan tidak dapat dipisahkan dari nafas. Sebab nafas adalah sumber vital kehidupan makhluk hidup. Ketika seorang bayi dilahirkan ke dunia, bernafas adalah hal pertama yang dilakukan, 
begitupun saat meninggal, kehilangan nafas atau gagal nafas adalah indikasinya, oleh sebab itu teknik dalam bernafas menjadi sangat penting, sebagai penghubung antara tubuh fisik dan mental manusia. Dengan memperluas, menguatkan nafas maka pikiran, tubuh fisik dan mental akan harmoni, segala toksin dan udara kotor di dalam tubuh terbuang dengan mudah. Pranayama yang disinergikan dengan yoga asanas, memaksimalkan suplai oksigen menuju paru-paru, seperti yang dijelaskan oleh (Ellsworth, Dr. Arby. 2010: 11-12) sebagai berikut:

"Similar to the processes in digestion and cellular function, breathing draws nutrients into your body and expels waste. Breath is the link between our physical and mental selves, and breath control, or Pranayama, is an important yoga practice that you should exercise separately and incorporate into the asana practice. Expanding and strengthening your breath and mind, then, coincides with streching and strengthening your body. Practicing pranayama means to control your internal pranic of breath, the alternate action of prana. while you intake the breath of life, you must also eliminate the toxins within the depths of your respiratory system. Pranayama replenishing fresh oxygen to your lungs and connecting your mind with your body"

Paru-paru manusia mempunyai kapasitas sekitar 6,000 cc, tetapi ketika bernafas normal kita hanya mempompa sekitar 600 cc udara setiap kali bernafas ke paru-paru. Dengan bernafas secara dalam, maka paru-paru akan lebih banyak mempompakan udara. Pada saat bernafas biasa, kita bernafas sebanyak 15-18 kali per menit; sedangkan dengan tekhnik bernafas dalam, maka kita hanya bernafas sebanyak 4 8 kali per menitnya. Itu artinya, pernafasan kita melambat dari 15 kali bernafas menjadi 4 kali bernafas per menit, sehingga denyut nadi dan jantung juga menurun. Hal ini secara otomatis akan menurunkan dan menstabilkan tekanan darah, menenangkan sistem saraf, menanggulangi stress, pikiran dan tubuh menjadi tenang sehingga kecemasan, dan emosi mereda, pada akhirnya segala jenis penyebab munculnya gangguan tidur atau insomnia dapat teratasi dengan baik.

Pranayama berasal dari bahasa sanskerta, prana artinya nafas, kekuatan hidup. Dan ayama artinya perluasan, pengembangan, pengendalian. Jadi pranayama dapat diartikan sebagai teknik mengendalikan pernafasan atau pengembangan kekuatan hidup. Ada beberapa teknik pranayama, diantaranya yakni nadi shodhana, kapalabhati pranayama, ujjayi pranayama, sitali pranayama, brahmari pranayama. Namun teknik pranayama yang paling cocok dan dianjurkan untuk ibu pasca melahirkan yang menderita baby blues sindrom dan post-partum depression adalah teknik brahmari pranayama. Sebab teknik pernafasan ini bersifat menenangkan, memacu pengaktifan energi lunar (bulan) dalam tubuh, untuk meredakan ketegangan, kemarahan dan kecemasan secara instan, sangat efektif untuk ibu yang menderita gangguan tekanan darah dan kecemasan berlebih, memberikan kelegaan dan meredakan sakit kepala, meningkatkan konsentrasi dan daya ingat, serta membangun kepercayaan diri. Bhramari pranayama atau yang sering disebut bernapas ala lebah (humming bee breath), berasal dari arti nama lebah India yang berwarna hitam yang disebut Bhramari.

Saat mendengungkan nafas, dalam posisi mulut tertutup, pita suara digetarkan terusmenerus sehingga terdengar seperti suara 'aum'. Getaran tersebut mampu merangsang bagian otak yakni, hipotalamus untuk melakukan aktivasi sistem korteks adrenal dengan mengirim sinyal ke kelenjar hipofisis agar tidak mensekresikan adrenocorticotropin (ACTH), sehingga ACTH yang tadinya menstimulasi lapisan luar kelenjar adrenal (korteks adrenal) untuk melepaskan sekelompok hormon (kortisol) justru gagal bertugas dan pada akhirnya kortisol tidak dihasilkan namun sebaliknya yang dihasilkan oleh otak justru endhorpine. Endorphin diproduksi oleh tubuh yaitu oleh kelenjar pituitary. Zat ini bertindak bahkan 200 kali lebih besar daripada morphine, yang berfungsi untuk kekebalan tubuh, mengatur emosi, merilekskan tubuh serta mampu menghilangkan depresi. Endhorpine merupakan unsur dari protein yang diproduksi oleh sel-sel tubuh serta sistem saraf manusia, munculnya 
dipicu melalui pranayama, relaksasi (sawasana), serta meditasi. Karena endorphine diproduksi oleh tubuh manusia sendiri, maka endorphine dianggap sebagai zat penghilang rasa sakit yang terbaik. Dengan kembalinya kemampuan tubuh ibu untuk menghasilkan endorphine yang cukup, maka hormon estrogen, progesterone, prolaktin dan estriol yang menurun drastis seketika sesaat setelah ibu melahirkan dapat kembali stabil, sehingga resiko baby blues sindrom dan postpartum depression dapat diminimalisir.

Pada akhir tahapan latihan brahmari pranayama, ibu dianjurkan melakukan tahapan meditasi yang hening beberapa saat untuk juga merangsang otak berada pada gelombang frekuensi $0,5 \mathrm{~Hz}$ atau $1 / 2 \mathrm{~Hz}$ yang dikenal dengan gelombang epsilon. Pada state ini, akan terjadi keseimbangan antara otak kiri dan otak kanan, kondisi yang tenang dan sangat hening, kondisi spiritual yang lebih tinggi sehingga pada akhirnya tubuh ibu sangat rileks, rasa nyeri yang ditimbulkan pasca melahirkan akan mereda dengan lebih cepat, tumbuhnya kepercayaan diri ibu yang berakibat pada kesehatan mentalnya, sehingga stressor fisik biologis, stressor psikologis dan stressor sosial budaya, tidak akan berpengaruh pada tubuh fisik dan mental ibu yang pada akhirnya 50-80\% ibu yang mengalami baby blues sindrom dan post-partum depression dapat pulih total seperti sebelum terjadinya kehamilan. Untuk menyempurnakan upaya ini, dibutuhkan dukungan lingkungan sekitar terutama dukungan suami dan keluarga besar, agar bayi dari si ibu dirawat dan diperhatikan dengan baik selama ibu melakukan chandra namaskara dan brahmari pranayama, selain juga dibutuhkannya dukungan berupa materiil dan non materiil.

Adapun teknik melakukan brahmari pranayama adalah: (1) Duduk tegak dengan kedua bahu dibuka, kedua mata ditutup, (2) Tempatkan kedua ibu jari pada tulang rawan telinga, kedua jari telunjuk pada dahi tepat di atas kedua alis, kedua jari tengah tepat di atas kedua kelopak mata yang tertutup, kedua jari manis pada hidung dan kedua jari kelingking tepat di atas lipatan bibir bagian atas, (3) Tarik nafas dalam melalui hidung, sampai dada mengembang. Kemudian dengan menekan keseluruh jari-jari tangan dengan lembut, hembuskan nafas seperti suara dengungan keras lebah dalam posisi mulut tetap tertutup. Teknik ini dilakukan sebanyak 6-7 kali. Brahmari pranayama juga dapat dilakukan sambil berbaring terlentang, dan dilakukan sebanyak 3-4 kali sehari.

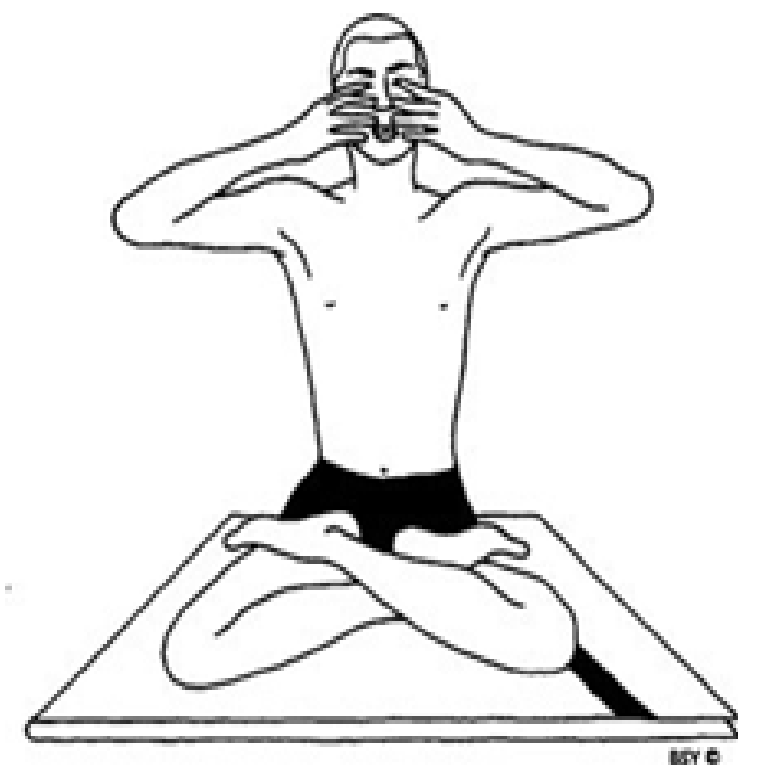

Sumber: https://www.google.com/search-bhramari+pranayama-client-firefox-b\&source/

\section{PENUTUP}

Dari pemaparan di atas, dapat disimpulkan bahwa baby blues sindrom dan post-partum depression yang dialami oleh 50-80\% ibu pasca melahirkan baik melalui prosedur normal maupun caesar (sc) disebabkan oleh tiga golongan stressor yakni: stressor fisik biologis (berupa perubahan hormonal yang drastis, nyeri pada payudara, nyeri pada daerah sekitar jalan lahir dan rahim serta kelelahan fisik), stressor psikologis (berupa munculnya rasa takut, cemas dan khawatir berlebih dalam menggeluti perannya sebagai ibu, hilangnya rasa percaya diri, merasa kehilangan identitas lama, merasa tidak menarik secara fisik dan seksual), dan stressor sosial budaya (ketidaksepahaman dengan suami dan keluarga, kurangnya perhatian dari suami dan orang terdekat dalam membantu merawat diri dan bayinya, juga dapat muncul akibat tuntutan adat terkait serangkaian pelaksanaan kegiatan adat setempat yang ditujukan untuk menyambut kelahiran bayinya. Apabila ancaman tersebut tidak segera ditangani secara khusus, maka akan membawa kerugian pada tubuh fisik dan mental 
ibu dan bayinya di masa yang akan datang berupa (1) akibat fisik: munculnya penyakit jantung dan pembuluh darah (kardiovaskuler), gangguan pada saluran pernafasan dan pencernaan, gangguan pertumbuhan jaringan dan tulang, nyeri kepala, ketegangan otot, dan penurunan sistem kekebalan tubuh yang mengakibatkan ibu rentan terserang infeksi. (2) akibat emosional : ibu cenderung mengisolasi diri dan menarik diri dari lingkungan sosialnya, juga besar kemungkinan memiliki niat bunuh diri dan membunuh anaknya sendiri. (3) akibat perilaku: mengakibatkan ibu mengalihkan perhatian pada hal-hal yang merugikan misalnya merokok, minum-minuman keras, menggunakan obat-obatan terlarang dan makan dalam jumlah berlebihan yang berakibat buruk bagi kesehatan ibu.

Untuk itu, chandra namaskara dan brahmari pranayama dapat menjadi teknik penyembuhan khusus pada ibu yang mengalami kedua jenis sindrom ini. Chandra namaskara pada ibu dengan persalinan normal dapat dilakukan mulai hari ke-3 pasca melahirkan, dan mulai hari ke-7 untuk ibu dengan persalinan caesar (sc) sesuai kemampuan tubuh fisik ibu tersebut. Dapat diberlakukan kelas pemula pada ibu yang sebelumnya, tidak pernah sama sekali melakukan latihan yoga asanas, dan tahapan pemula-menengah pada ibu yang sebelumnya sudah pernah ikut latihan yoga asanas. Secara khusus, pranamasana, hasta uttahanasana, padahastasana, ashwa sanchalanasana, dan ardha chandrasana mampu mengurangi tekanan udara pada sendi antar tulang vertebra dan membantu mengurangi rasa sakit pada punggung dan pinggang ibu. Postur tersebut menghasilkan traksi alami pada kolom tulang belakang, mengembalikan kekuatan intrinsik pada otot yang dapat mencegah terjadinya prolapsed disc di kemudian hari. Sirkulasi atau perubahan artritis pada sendi tulang belakang dapat dihilangkan dengan peregangan pada otot-otot para-spinal dan ligamen antar tulang vertebra melalui serangkaian asanas Chandra namaskara ini.

Sedangkan brahmari pranayama bersifat menenangkan, memacu pengaktifan energi lunar (bulan) dalam tubuh, untuk meredakan ketegangan, kemarahan dan kecemasan secara instan, sangat efektif untuk ibu yang menderita gangguan tekanan darah dan kecemasan berlebih, memberikan kelegaan dan meredakan sakit kepala, meningkatkan konsentrasi dan daya ingat, serta membangun kepercayaan diri. Saat mendengungkan nafas, dalam posisi mulut tertutup, pita suara digetarkan terus-menerus sehingga terdengar seperti suara 'aum'. Getaran tersebut mampu merangsang bagian otak yakni, hipotalamus untuk melakukan aktivasi sistem korteks adrenal dengan mengirim sinyal ke kelenjar hipofisis agar tidak mensekresikan adrenocorticotropin (ACTH), sehingga ACTH yang tadinya menstimulasi lapisan luar kelenjar adrenal (korteks adrenal) untuk melepaskan sekelompokhormon(kortisol)justru gagal bertugas dan pada akhirnya kortisol tidak dihasilkan namun sebaliknya yang dihasilkan oleh otak justru endhorpine. Zat ini bertindak bahkan 200 kali lebih besar daripada morphine, yang berfungsi untuk kekebalan tubuh, mengatur emosi, merilekskan tubuh serta mampu menghilangkan depresi. Pada akhir tahapan latihan brahmari pranayama, ibu dianjurkan melakukan tahapan meditasi yang hening beberapa saat untuk juga merangsang otak berada pada gelombang frekuensi $0,5 \mathrm{~Hz}$ atau $1 / 2 \mathrm{~Hz}$ yang dikenal dengan gelombang epsilon, dengan demikian 50-80\% ibu yang mengalami baby blues sindrom dan post-partum depression dapat pulih total seperti sebelum terjadinya kehamilan. Untuk menyempurnakan upaya ini, dibutuhkan dukungan lingkungan sekitar terutama dukungan suami dan keluarga besar, agar bayi dari si ibu dirawat dan diperhatikan dengan baik selama ibu melakukan chandra namaskara dan brahmari pranayama, selain juga dibutuhkan dukungan secara moriil dan materiil.

\section{DAFTAR PUSTAKA}

Aisyah, Nur Siti, 2010. Belajar Psikologi Faal. Surabaya: IAIN Press.

Chinmayananda, Swami. 2008. Meditation And Life. India: Central Chinmaya Mission Trust.

Coulter, H. David. 2010. Anatomy Of Hatha Yoga A Manual For Students, Teachers, And Practitioners. Delhi: Motilal Banarsidass 
Publishers.

Ellsworth, Abby. 2010. Anatomy Of Yoga An Insiders Guide To Improving Your Poses. China: Hinkler Books Pty Ltd.

Gondosari, H. Aleysius. 2010. The Secret Of Five Elements. Jakarta: PT. Gramedia Pustaka Utama.

Iyengar, B.K.S. 2000. Light On Yoga. India: Gopsons Papers.

Kumar, Kamakhya. 2006. A Hand Book Of Yoga Therapy. India: Dev Sanskriti Vishwavidyalaya.

Pudja, G. M.A., Sudharta, Tjokorda Rai, M.A., 2002. Manawa Dharmasastra ( Manu Dharma Sastra) atau Weda Smrti Compendium Hukum Hindu. Jakarta: CV. Felita Nusantara Lestari.

Saraswati, Swami Satyananda. 2013. Asana Pranayama Mudra Bandha. India: Yoga Publications Trust.

Snell, Richard S. 1995. Anatomi Klinik Untuk Mahasiswa Kedokteran. Jakarta: Penerbit Buku Kedokteran EGC.

https://id.wikipedia.org/wiki/Hari_Ibu, diunggah pada 22-12-17, diunduh: 28-02-2018.

https://dokterindonesiaonline.com/2014/08/21/ kenali-baby-blues-syndrome-dan-gangguanjiwa-paska-melahirkan-lainnya/, diunduh: 01-03-2018

http://pranayoga.co.in/asana/chandra-namaskarmoon-salutation/, diunduh: 05-03-2018

https://www.google.com/searchbhramari+pranayama-client-firefoxb\&source/, diunduh: 05-03-2018 